\title{
Vaginal Clear Cell Adenocarcinoma
}

National Cancer Institute

\section{Source}

National Cancer Institute. Vaginal Clear Cell Adenocarcinoma. NCI Thesaurus. Code C7735.

A morphologic variant of adenocarcinoma affecting the vagina. It is characterized by the presence of malignant glandular epithelium and clear cells containing glycogen. 